\title{
Morphology and histology of acanthodian fin spines from the late Silurian Ramsåsa E locality, Skåne, Sweden
}

\author{
Anna Jerve, Oskar Bremer, Sophie Sanchez, and Per E. Ahlberg
}

\begin{abstract}
Comparisons of acanthodians to extant gnathostomes are often hampered by the paucity of mineralized structures in their endoskeleton, which limits the potential preservation of phylogenetically informative traits. Fin spines, mineralized dermal structures that sit anterior to fins, are found on both stem- and crown-group gnathostomes, and represent an additional potential source of comparative data for studying acanthodian relationships with the other groups of early gnathostomes. An assemblage of isolated acanthodian fin spines from the late Silurian Ramsåsa site $E$ locality (southern Sweden) has been reconstructed in 3D using propagation phase contrast synchrotron $\mathrm{X}$-ray microtomography (PPC-SR $\mu \mathrm{CT}$ ). The aim is to provide morphological and taxonomical affinities for the spines by combining morphology and histology with the taxonomical framework previously established for the site mainly based on isolated scales. The high-resolution scans also enable investigations of the composition and growth of acanthodian fin spines when compared to similar studies of extinct and extant gnathostomes. In total, seven fin spine morphotypes that have affinities to both Climatiidae Berg 1940 and Ischnacanthiformes Berg 1940 are described. The majority are interpreted as median fin spines, but three possible paired spines are also identified. The spines display differences in their compositions, but generally agree with that presented for climatiids and ischnacanthiforms in previous studies. Their inferred growth modes appear to be more similar to those of fossil and extant chondrichthyan fin spines than to those described from placoderms and stem-osteichthyans, which is congruent with the emerging view of acanthodians as stem-chondrichthyans.
\end{abstract}

Anna Jerve. Biology Department, Imperial College London, Silwood Park Campus, Buckhurst Road, Ascot, SL5 7PY, United Kingdom. a.jerve@ic.ac.uk

Oskar Bremer. Department of Organismal Biology, Uppsala University, Norbyvägen 18A, 752 36, Uppsala, Sweden. Corresponding author. bremer.oskar@gmail.com

Sophie Sanchez. Science for Life Laboratory and Uppsala University, Department of Organismal Biology, Norbyvägen 18A, 75236 Uppsala, Sweden and European Synchrotron Radiation Facility, 71 Avenue des Martyrs, 38000 Grenoble, France. sophie.sanchez@ebc.uu.se

Per E. Ahlberg. Department of Organismal Biology, Uppsala University, Norbyvägen 18A, 752 36, Uppsala, Sweden.Per.Ahlberg@ebc.uu.se

Jerve, Anna, Bremer, Oskar, Sanchez, Sophie, and Ahlberg, Per E. 2017. Morphology and histology of acanthodian fin spines from the late Silurian Ramsåsa E locality, Skåne, Sweden. Palaeontologia Electronica 20.3.56A: 1-19. https://doi.org/10.26879/749

palaeo-electronica.org/content/2017/2062-ramsasa-acanthodian-fin-spines

Copyright: November 2017 Palaeontology Association.

This is an open access article distributed under the terms of Attribution-NonCommercial-ShareAlike 4.0 International (CC BY-NC-SA 4.0 ), which permits users to copy and redistribute the material in any medium or format, provided it is not used for commercial purposes and the original author and source are credited, with indications if any changes are made.

creativecommons.org/licenses/by-nc-sa/4.0/ 
Keywords: fin spines; histology; acanthodians; 3D-reconstructions; Silurian; Baltic Basin

\section{INTRODUCTION}

Acanthodians were once considered to form a clade found worldwide in rocks ranging in age from Silurian to late Permian, and united partly by the presence of median and paired fin spines (Denison, 1979). However, paired fin spines have now been described from early chondrichthyans (Miller et al., 2003) and paired and median spines have been discovered on a handful of fossil osteichthyans (Zhu et al., 1999, 2009). These discoveries, along with cranial data, have led to the rejection of a monophyletic Acanthodii (Brazeau, 2009; Davis et al., 2012) and to new ideas about how these animals relate to osteichthyans and chondrichthyans. The working hypothesis of vertebrate phylogeny has now shifted to accept acanthodians as a paraphyletic assemblage within the chondrichthyan total group (Zhu et al., 2013; Giles et al., 2015; Burrow et al., 2016; Qiao et al., 2016).

Osteichthyans and placoderm fossils are known by their bony skeletons, but chondrichthyans and acanthodians have only a few skeletal elements that commonly preserve, including scales, teeth, jaws, head tesserae, scapulae, and fin spines. The presence of fin spines and spiny elements in all these groups of jawed vertebrates has highlighted the importance of understanding their development and evolution. Studies of the development and growth of extant chondrichthyan fin spines (Markert, 1896; Maisey, 1979; Jerve et al., 2014) has provided a framework from which to understand fossil spines. Furthermore, the use of propagation phase-contrast synchrotron X-Ray microtomography technology as a nondestructive tool for studying the 3D microstructure of fossils has made it possible to understand aspects of their overall architecture that might not be observed from traditional 2D thin section (e.g., Sanchez et al., 2012; Qu et al., 2015). This technique has been used to study the histology of a number of fossils, including scales (e.g., Qu et al., 2013, 2015), dermal plates (e.g., Dupret et al., 2010; Giles et al., 2013; Chen et al., 2016), fin bones and rays (Sanchez et al., 2014), and fin spines (Jerve et al., 2016), and has provided valuable information on the morphology, vascularization, and growth of these structures.

Fossils collected from the now inaccessible late Silurian Ramsåsa site $E$ locality in Skåne, southern Sweden, include well preserved, albeit fragmentary and isolated remains of acanthodian spines and shoulder girdles, together with other isolated vertebrate remains. Vergoossen (2004) described the micro-remains in residues from Ramsåsa site $E$ samples with the aim of providing a paleontological and taxonomical framework for both the micro-vertebrate and macro-remains. Besides reporting osteostracans, thelodonts, and anaspids, Vergoossen (2004) also described several acanthodian scales and fragments, and referred them to a number of scale-based taxa. However, most of the macro-remains have remained undescribed and have not yet been taxonomically identified.

Here, we describe the morphology of seven fin spine morphotypes identified from the Ramsåsa collection held at the Naturhistoriska Riksmuseet (NRM) in Stockholm, Sweden. With the aid of the micro-vertebrate framework presented by Vergoossen (2004), and by comparing them to described articulated material (see later sections), we aim to give these vertebrate remains taxonomical and morphological assignments. Given the current close phylogenetic position of acanthodians to chondrichthyans based on recent hypotheses (Zhu et al., 2013; Giles et al., 2015; Burrow et al., 2016; Qiao et al., 2016) it is necessary to understand how similar their fin spines are in terms of morphology and growth. The morphology and histology are investigated (where possible) from synchrotronmicrotomography data collected from the European Synchrotron Radiation Facility in Grenoble, France. These data are used to compare the Ramsåsa fin spines to other fossil taxa and the current growth models for extant sharks described by Maisey (1979), Tovar-Ávila et al. (2008), and Jerve et al. (2014).

\section{GEOLOGICAL SETTING}

The Öved-Ramsåsa Group crops out in three areas in Skåne, Southern Sweden: the Ringsjö area, the Bjärsjölagård-Övedskloster area, and the Ramsåsa area. The Ramsåsa area (Figure 1) is the southeasternmost of these and is represented by a series of old quarries (sites A-H in Grönwall, 1897). The only site still accessible (site F) is referred to as Ramsåsa 8 in Jeppsson and Laufeld (1986). This is also where the first Ramsåsa fish 


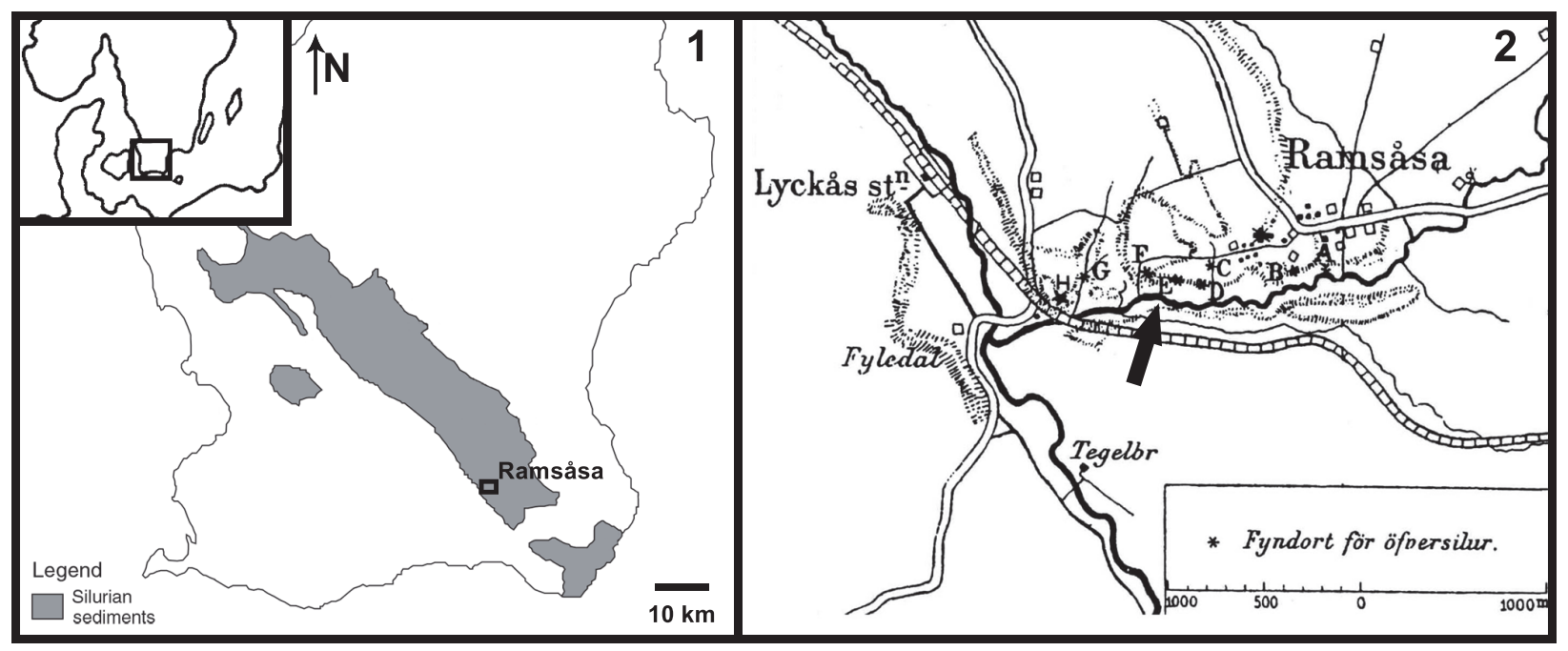

FIGURE 1. Map modified from Mehlqvist et al. (2014) showing the location of the Ramsåsa area (1), and the Ramsåsa localities of Grönwall (1897) with an arrow indicating site E (2) adapted from Vergoossen (2004).

faunas were described from by Lehman (1937). The material used in this study comes from Ramsåsa site $E$ (Figure 1), which was a small grindstone quarry that is now destroyed (Larsson, 1979; Vergoossen, 2004).

The Öved-Ramsåsa Group is divided by Jeppsson and Laufeld (1986) into the Klinta Formation (including Lunnarna, Bjär, Bjärsjö and Bjärsjölagård members) and the Öved Sandstone Formation. The group has been dated to span from Ludlow (Ludfordian) to Pridoli (Jeppsson and Laufeld, 1986; Siveter, 1989), but the upper part of the Öved Sandstone has recently been proposed to extend into the Lower Devonian based on palynostratigraphical data (Mehlqvist et al., 2015). According to Vergoossen (2004), the sediments at site E corresponded to layer 4 in Grönwall (1897), which was dated as Pridoli by Jeppsson and Laufeld (1986).

The sediments of the Öved-Ramsåsa Group were deposited in the epicontinental Baltic Basin and reflect a gradual shallowing-upward sequence (Jeppsson and Laufeld, 1986). The group is dominated by mudstones that are sometimes tidal-influenced and inter-layered with shallow marine carbonates (Wigforss-Lange, 1999, 2007). The lower Klinta Formation contains grey mudstones intercalated by silt- and limestones that grade into the carbonate-rich Bjärsjölagård Limestone Member, and is subsequently overlain by the Öved Sandstone Formation (Jeppsson and Laufeld, 1986). The Öved Sandstone is dominated by sandstones and shales, but it also contains thin limestone beds with marine faunas (Jeppsson and
Laufeld, 1986). According to Jeppsson and Laufeld (1986), many levels of the sandstone also contain marine faunas, but an increased importance of bivalves among the macrofossils indicates shallowing upward and some levels may be non-marine. The lithology at Ramsåsa site $E$ has been described as reddish-brown silty mudstones and micaceous siltstone (Vergoossen, 2004).

\section{MATERIALS AND METHODS}

The acanthodian fin spines from Ramsåsa site $E$ described in this study were collected by Carl Pleijel and stored in Tor Ørvig's collection (Vergoossen, 2004). They are part of a larger collection that also includes other macro-remains prepared by Carl Pleijel, and are now housed at the Naturhistoriska Riksmuseet (NRM) (see caption of Figure 2.1-2.7 for specimen numbers). Each specimen was photographed using a Nikon D200 with a Nikkor 1.4/f $50 \mathrm{~mm}$ lens and the RAW image was processed using Adobe Photoshop 6. The illustrations were originally created using a camera lucida that were then drawn again in vector format in Adobe Illustrator 6 .

The fin spines were scanned at the European Synchrotron Radiation Facility (beamline ID19, France) using three different set-ups to scan the samples with a voxel size of $5.05 \mu \mathrm{m}$ and 0.678 $\mu \mathrm{m}$.

The $5.05-\mu \mathrm{m}$ scans were performed using a pink beam filtered with $2 \mathrm{~mm}$ of aluminum, 0.25 $\mathrm{mm}$ of copper and $0.25 \mathrm{~mm}$ of tungsten. In addition, the wiggler's gap was opened to $50 \mathrm{~mm}$ to provide a beam with the energy of about $69.3 \mathrm{keV}$. 


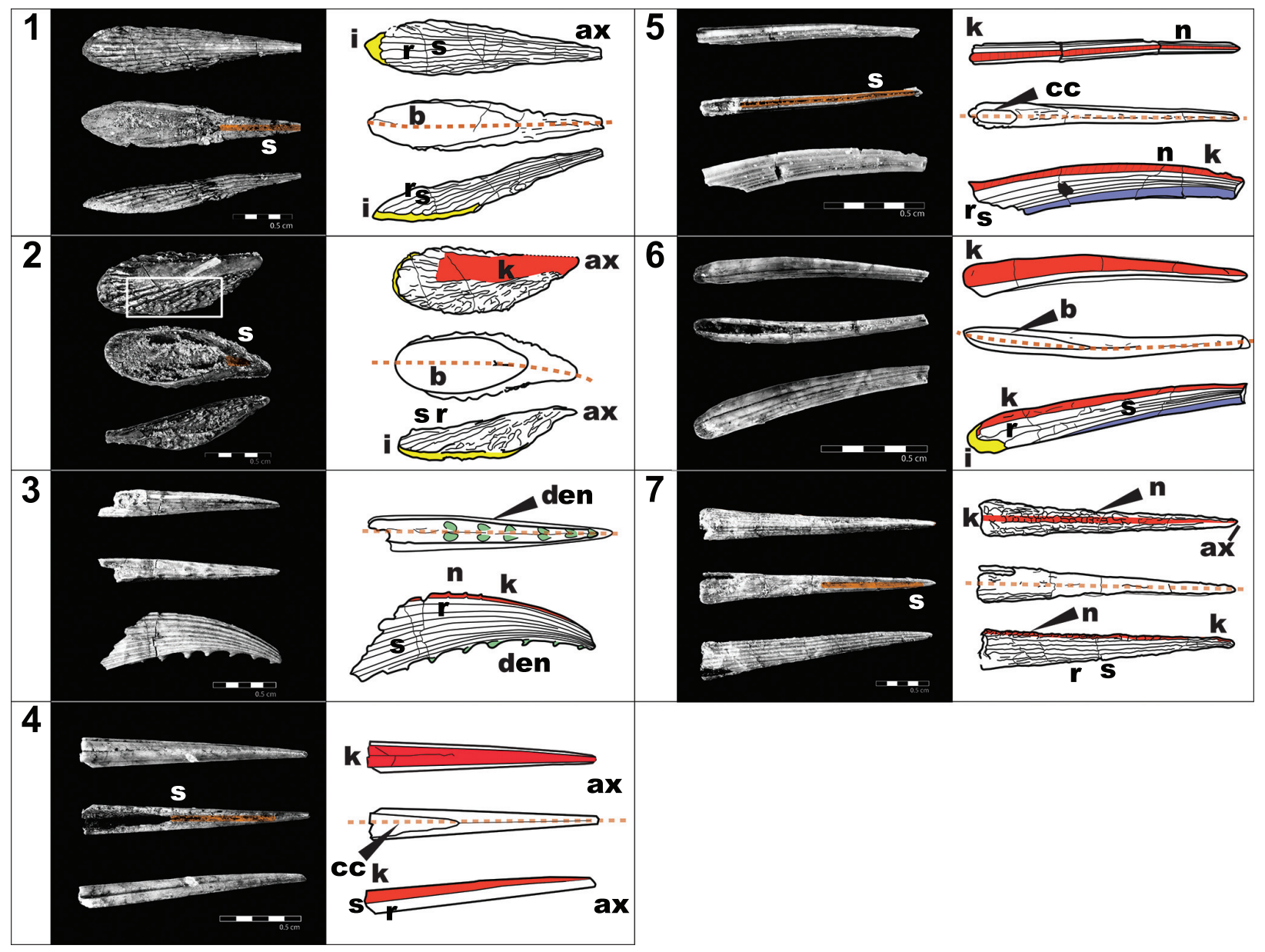

FIGURE 2. Photographs and illustrations of the seven fin spine morphotypes (A-G) from the Ramsåsa locality in Skåne, southern Sweden. (1), morphotype A (NRM-PZ P. 16173); (2), morphotype B (NRM-PZ P. 16174); (3), morphotype C (NRM-PZ P. 16175); (4), morphotype D (NRM-PZ P. 16176); (5), morphotype E (NRM-PZ P. 16177); (6), morphotype F (NRM-PZ P. 16178); and (7), morphotype G (NRM-PZ P. 16179). Each spine is shown in dorsal (top), ventral (middle), and left-lateral (bottom) views. A dotted line indicates the spine midlines. Abbreviations: ax, apex; $b$, base; cc, central cavity; den, denticle; i, insertion; k, keel/anterior rib; n, node; r, rib; s, sulcus. Color coding indicates the keel: red; insertion: yellow; posteriorly facing nodes/denticles: green; longitudinal sulcus along the posterior surface: orange; wide posterior surface: blue.

The optics was coupled to a $125-\mu m$-thick LuAG scintillator and a Frelon 2k14 CCD camera (fast readout low noise) (Labiche et al., 2007). The sample was fixed at $1100 \mathrm{~mm}$ from the detector. 1999 projections were taken over $360^{\circ}$ with a time of exposure of $0.1 \mathrm{~s}$.

The high-resolution scan data (voxel size: $0.678 \mu \mathrm{m})$ result from two different set-ups. Morphotype A was imaged with a monochromatic beam at the energy of $52 \mathrm{keV}$ fixed by the use of a single crystal $2.5 \mathrm{~nm}$ period W/B4C multilayer monochromator. The beam was filtered with 0.25 $\mathrm{mm}$ of copper and $2 \mathrm{~mm}$ of aluminum. The gap of the undulator $\mathrm{U} 32 \mathrm{u}$ was opened to $11.7247 \mathrm{~mm}$. 1999 projections were taken over $360^{\circ}$ with a time of exposure of $1 \mathrm{~s}$. The distance of propagation was of $70 \mathrm{~mm}$ to increase the phase contrast effect. A YAG:Ce 25- $\mu$ m-thick scintillator was mounted on the optical system and coupled to a Frelon CCD camera (Labiche et al., 2007).

Morphotypes $\mathrm{C}$ and $\mathrm{G}$ were scanned at 30 $\mathrm{keV}$. A single crystal $2.5 \mathrm{~nm}$ period W/B4C multilayer monochromator was used and the beam was filtered with $2 \mathrm{~mm}$ of aluminum. The gap of the undulator U32u was fixed to $12.38 \mathrm{~mm}$. 2000 projections were taken over $180^{\circ}$. The time of exposure was of $0.3 \mathrm{~s}$. The sample was set to a propagation distance of $30 \mathrm{~mm}$. The scintillator was a 10- $\mu$ m-thick GGG (Martin et al., 2009) and 


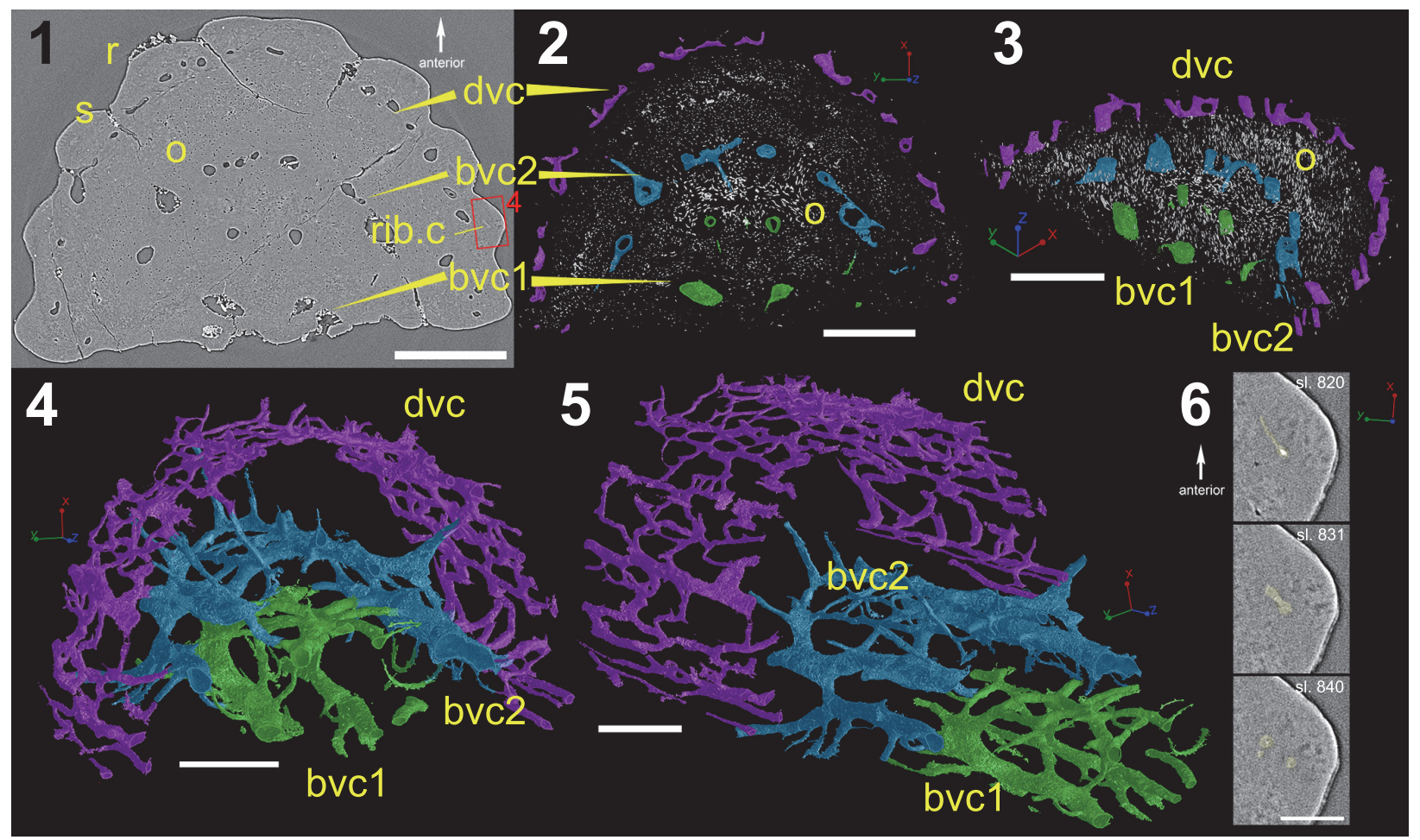

FIGURE 3. High-resolution (voxel size: $0.678 \mu \mathrm{m}$ ) synchrotron data of fin spine morphotype A. (1), virtual thin section (slice 1535) showing the general morphology and internal organization of the vascular canals and osteocyte lacunae. $(2,3)$, segmented data illustrating the organization of vascular canals and cell spaces, and, $(4,5)$, the reconstructed data deconstructed to show each component. (6), virtual thin sections of magnified portion of ribbing, showing the ribbing canals from slices 820,831 , and 840 . Red box in (1) shows the position of the magnified portion of the fossil. Abbreviations: bvc1,2, bone vascular canals (layers 1 or 2); dvc, dentine vascular canals; o, osteocyte spaces; r, rib; rib.c, ribbing canals; s, sulcus. Scale bars equal $250 \mu \mathrm{m}$.

the detector a Frelon CCD camera (Labiche et al., 2007).

All the images were reconstructed using a filtered back projection algorithm (PyHST software, ESRF) in edge detection mode (Sanchez et al., 2012). The segmentation was done using VG StudioMax 2.2 (Volume Graphics, Germany).

\section{RESULTS}

Morphotype A (Figure 2.1) is represented by a tear-drop shaped, straight fin spine that is bilaterally symmetrical (midline marked by dotted line). The apex of the spine tip (Figure 2.1; ax) is missing, but the closed part of the spine is evidently shorter than, or at least no more than the same length as, the length of the open part of the spine base (Figure $2.1 ; b$ ). The open part of the fin spine base is oval in shape in proximal view and it has a small, unornamented section at the base that indicates a shallow insertion (Figure 2.1 ; $i$ in yellow). The posterior side of the closed part of the spine has small longitudinal sulcus (Figure 2.1; $\mathrm{s}$ in orange) running along it for attachment with the fin. This morphotype is ornamented with continuous, evenly spaced longitudinal ribs (Figure 2.1; $r$ is white) that merge apically. The ribs are usually wider than the sulcus (Figure 2.1; s as black lines on the illustrations) that separates them.

The segmented high-resolution synchrotron data was taken through the closed distal portion of the fin spine and clearly shows the vascularization and bone cell lacunae within it (Figure 3). The most obvious histological feature of the scan slice in Figure 3.1 is the vascularization, but bone cell spaces (modeled in white on Figure 3.2, 3.3) are also abundant throughout the bulk of the fin spine, although absent in the ribbing. This suggests that cellular bone is the major hard tissue comprising the spine.

The vascularization is divided into three layers (bvc1, bvc2, dvc), each of which is mainly formed of longitudinal vascular canals (Figure $3.4,3.5$ ) that are anastomosed to each other. The three layers are connected to each other with radial canals (Figure 3.5). The innermost layer of canals (Figure 3.4; 
bvc1) creates a small arched, or square, cluster of canals that neatly connects to a larger arch of bone vascular canals (Figure 3.5; bvc2) by short, narrow radial canals. The outer layer of vascular canals is called dentine vascular canals (Figure 3; dvc), as they are associated with the dentinous outer ornamentation. Ribbing canals (rib.c) are present in the ornamenation of this morphotype, which can be observed easily in the datasets but are difficult to segment (Figure 3.6).

The ribbing is most likely composed of dentine, but there is no clear boundary marked in the tissue indicating the transition from bone to dentine. However, bone cell spaces do not extend beyond the boundary of the outer layer of vascular canals. Some of the bone cell spaces appear to be flattened and located in circular layers around the bone vascular canals of the innermost layers (Figure 3.1-3.3; bvc1 and bvc2), indicating that there are osteons within the bone.

Morphotype B (Figure 2.2) is represented in its entirety by a short spine that has a tear-drop shaped outline. It differs from morphotype $A$ in its asymmetry and because the apex of the spine is much shorter than the length of the open oval shaped part of the base (Figure 2.2). The ornamentation on this morphotype is ribbed anteriorly and noded posteriorly, with some nodes merging together to create a rib (orange rectangle). All ribs converge at the anterior facing part of the spine to create a smooth, wide rib, or keel (Figure 2.2; $\mathrm{k}$ in red), that extends to the tip of the spine. The insertion for this spine (Figure 2.2) is unornamented and thin. There is no histological information for this morphotype at present.

Morphotype C (Figure 2.3) is represented by a fragment of the closed part of a recurved spine that includes a partial apex. The spine body is laterally compressed and slightly asymmetrical. This spine is ornamented with evenly spaced narrow ribbing with wider sulci that converge at the tip of the spine (Figures 2.3 and 4). There is a leading-edge rib (Figure 2.3) that is roughly the same size as the lateral ribs. All ribbing is continuous along the length of the spine fragment, but the most anterior ribs have small nodes along their length (Figure 2.3). The posterior surface of the spine is flat and narrow, and carries two parallel rows of six evenly spaced posteriorly facing nodes/denticles (Figure 2.3; den in green).

The high-resolution scan data (Figure 4.1-4.3) and 3D reconstructions (Figure 4.4-4.6) of the tipward portion of this spine does not reveal any cell spaces in the body of the spine, but resolves the vascularization and details of the morphology very well. The absence of bone cell lacunae and laminations, around the central cavity, suggest that the fin spine is most likely composed of dentine. The central cavity (Figure 4; cc) is triangular in shape and tapers tipward.

The vascularization is divided into different layers of vascular canals (Figure 4.7): canals located within the main tissue of the spine, including a posteriorly placed median canal (med.c in yellow), trabecular canals (trab.c in green), and vascular canals associated with the ornamentation, designated here as nodal canals (nod.c in orange) and ribbing canals (rib.c in purple). The median canal of the spine (Figure 4; med.c in yellow) is tall, thick, and laterally compressed, and runs longitudinally along the length of the spine. It is connected to the central cavity by short radial arms. The median canal connects the left and right sides of the trabecular and denticle canals on the posterior side, and also opens to the surface of the spine through a series of basal canals (Figure 4.5; bas.c). Trabecular canals (Figure 4.7-4.10; trab.c in green) radiate densely from the central cavity and are flat and narrow. These canals eventually connect with the ribbing canals that are characterized by short, horizontally looped networks that run the length of the spine under the ribbing (compare Figure 4.4 to 4.8). The nodal canals are associated with the two parallel rows of posteriorly facing nodes on the posterior surface of the spine (Figure 4.8-4.10). The canals that are located at the distal ends of the denticles/nodes are very small, round and form loops that eventually connect to one or two thicker and short radial canals. The thicker canals eventually connect to a small network of longitudinal canals (Figure 4.7) that form the two low ridges on the posterior surface on which the denticles/nodes sit (Figure 4.8-4.10). The purple ribbing canals appear to be short, looping, elongated canal networks that are associated with each rib (Figure 4.7 and 4.10).

Morphotype $D$ (Figure 2.4) is represented by a fragment along the closed part of a straight spine. This spine fragment is symmetrical and composed of one wide and rounded anterior rib/keel comprising the leading edge and one rounded rib on either side that are separated by narrow sulci. The posterior surface of this spine is flat with a shallow sulcus running along the midline. A variant of this morphotype is found among the Ramsåsa collection, which has many micro-striae on the lateral ribs. 


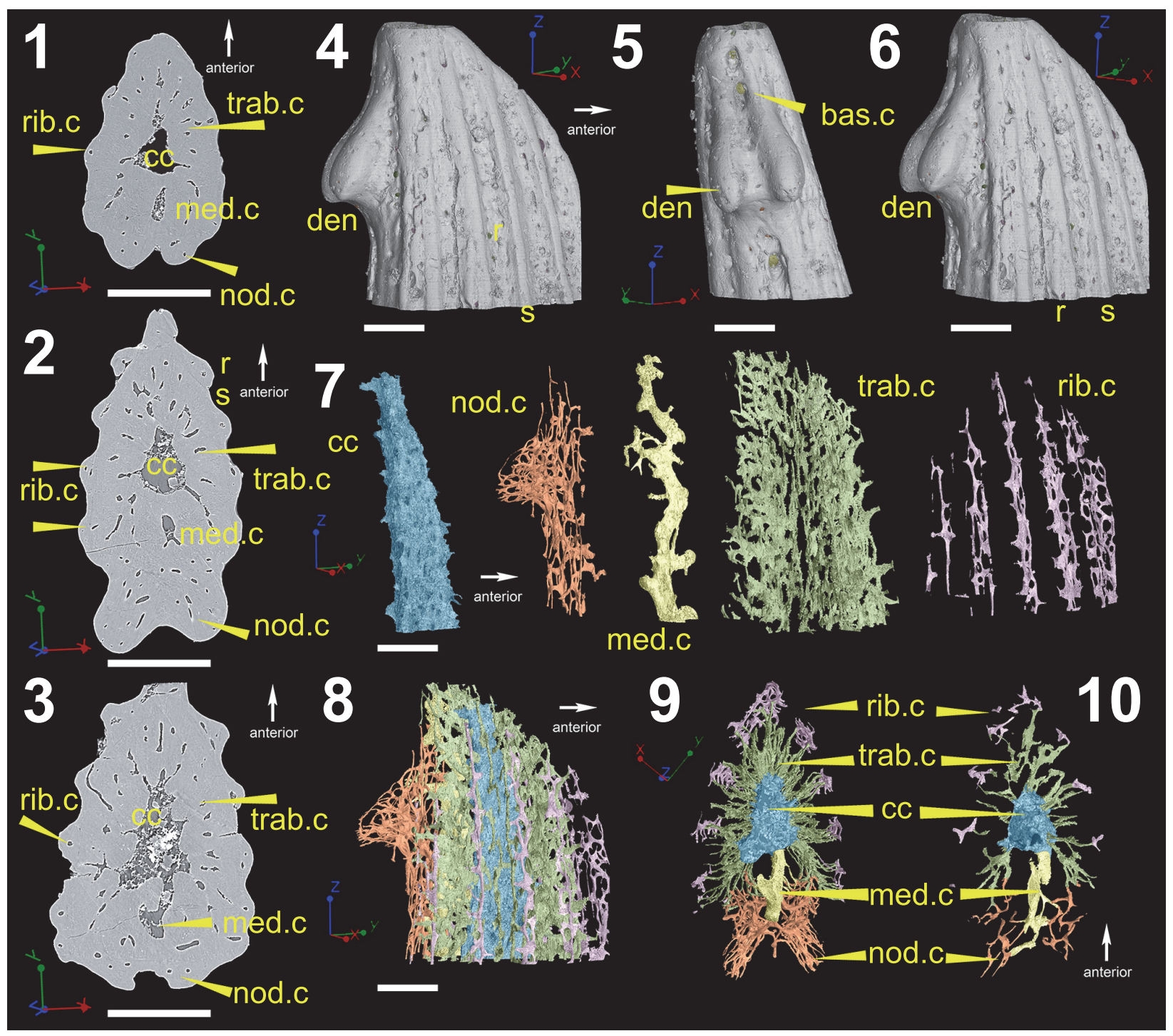

FIGURE 4. High-resolution (voxel size: $0.678 \mu \mathrm{m}$ ) synchrotron data of fin spine morphotype C, including virtual thin sections of (1), slice 1377; (2), slice 992; and (3), slice 12. (4-6) Reconstructions of the scanned fin spine showing the ornamentation. (7), Fin spine vascularization deconstructed into different parts and, (8), show all parts of the vascularization together, (9), in cross-sectional view with all canals from the scan, and (10), in cross-sectional view of isolated number of canals. (7-10) use the same colors. Scale bars equal $300 \mu \mathrm{m}$. Abbreviations: bas.c, basal canal; den, denticle; cc, central cavity; med.c, median canal; nod.c, node canals; r, ribbing; rib.c, ribbing canals; s, sulcus; trab.c, trabecular dentine canals.

This morphotype has a ring of what appears to be a compact bone (Figure $5 ; \mathrm{cb}$ ) around a round central cavity. The bone layer is thick near the tip of the spine but grows thinner as the cavity widens, becoming very thin, or absent, at the base (Figure 5.1-5.5). There are a few short, round canals radiating from the lateral and anterior parts of the central cavity into the layer of compact bone (Figure 5.6). These canals connect with a set of larger vascular canals that taper in size away from the central cavity. The density of vascular canals also decreases away from the central cavity (Figure 5.7), and the distal parts of the ribs appear to have no large longitudinal vascular canals, except for a few very small and radial canals (Figure 5.3).

Morphotype $E$ (Figure 2.5) is represented by a fragment of the closed end of a laterally compressed, slightly recurved spine. Both the base and the apex are missing from this section, but it is still included due to its unique morphology. The posterior surface of the spine is flat with a deep sulcus running down the midline. The central cavity of the 


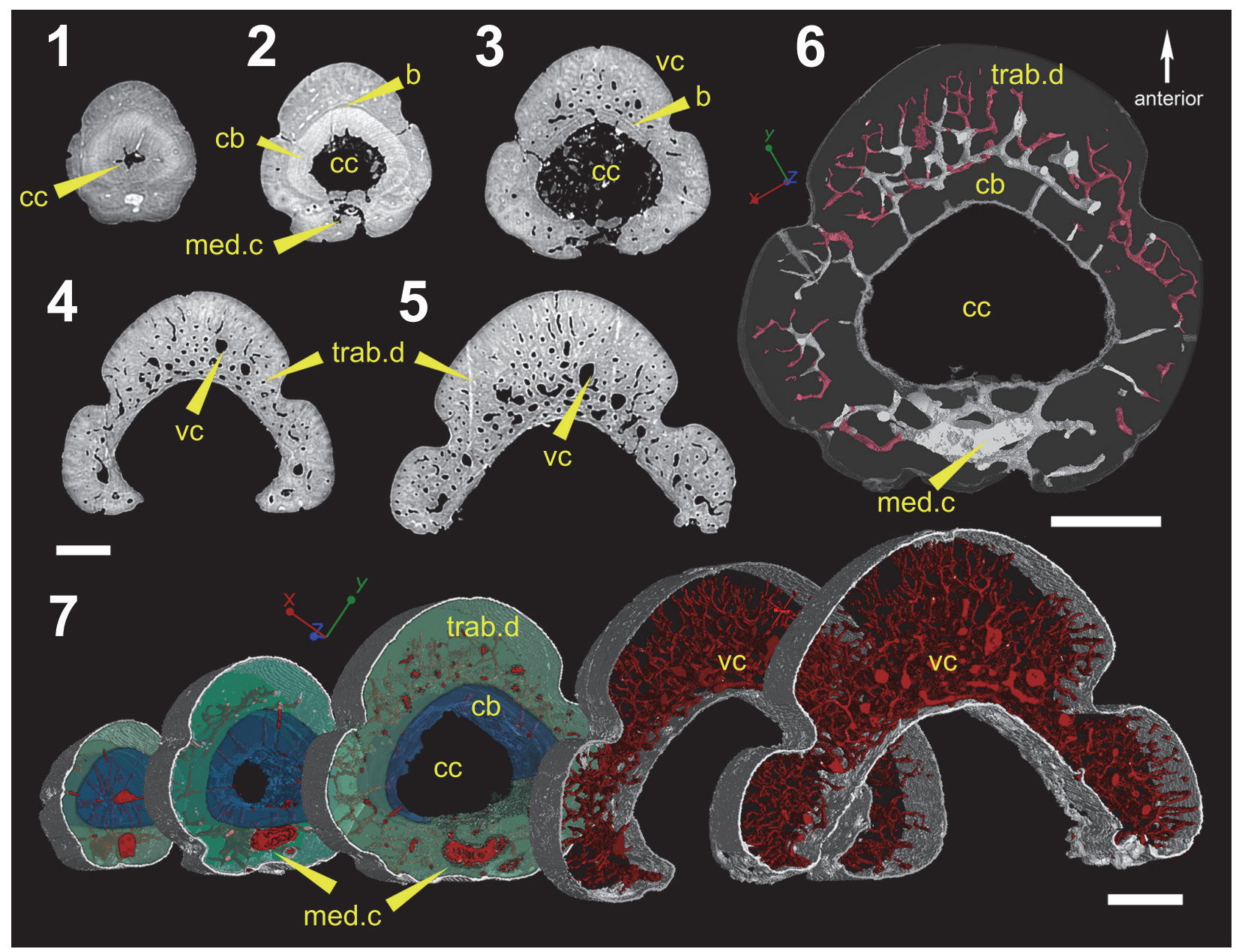

FIGURE 5. Low-resolution (voxel size: $5 \mu \mathrm{m}$ ) synchrotron data of fin spine morphotype D, including virtual thin sections of slice (1), 2596; (2), slice 2155; (3), slice 1524; (4), slice 886 and; (5), slice 222. (6), Segmented data that approximate to the scan slices 1-5, illustrating the vascularization and composition of the fin spine. (7), High-resolution (voxel size: $0.678 \mu \mathrm{m}$ ) synchrotron data 3D reconstruction illustrating the vascular organization of the fin spine. Scale bars equal $250 \mu \mathrm{m}$. Abbreviations: b, basal layer; cb; compact bone; cc, central canal; med.c, median canal; trab.d, trabecular dentine; vc, vascular canal.

spine is narrow, ovoid, and smooth. Ornamentation on the lateral surfaces of this morphotype is split up into three sections: the anterior keel, which is tall and narrow, and shows a tile-like ornamentation on the posterior half of the fragment (Figure 2.5); middle ribbing which is widely set proximally and closely set apically; and a wide surface with no ornamentation on the posterior part of the lateral surface (in blue). The middle ribs on the lateral surface of this morphotype look more angular due to a wider sulcus relative to the ribs. The reduction in size and the convergence of the middle ribbing shorten the distance between the anterior keel and posterolateral surface apically.

Virtual thin sections taken from low-resolution data (Figure 6.1) reveal that this morphotype has ribbing canals, though it is not as highly vascular- ized as morphotypes $C$ and $D$. There appears to be a layer of tissue surrounding the ovoid central cavity (Figure 6.1) that has a few radial canals running through it. Posterior to the central cavity, there is a large void space that could be the median canal (Figure 6.1), but could also be the deep sulcus that runs down the posterior midline of the spine (Figure 2.5). It is, however, unclear to discern from Figure 6.1 making it necessary to segment this out in the future.

Morphotype $\mathrm{F}$ (Figure 2.6) is represented by a slightly asymmetrical, slender, and narrow spine. The specimen has a complete base (Figure 2.6), but the apex and most likely part of the insertion (Figure 2.6) are missing. The closed part of the spine was probably longer than the open part of the spine. The posterior surface is narrow and 

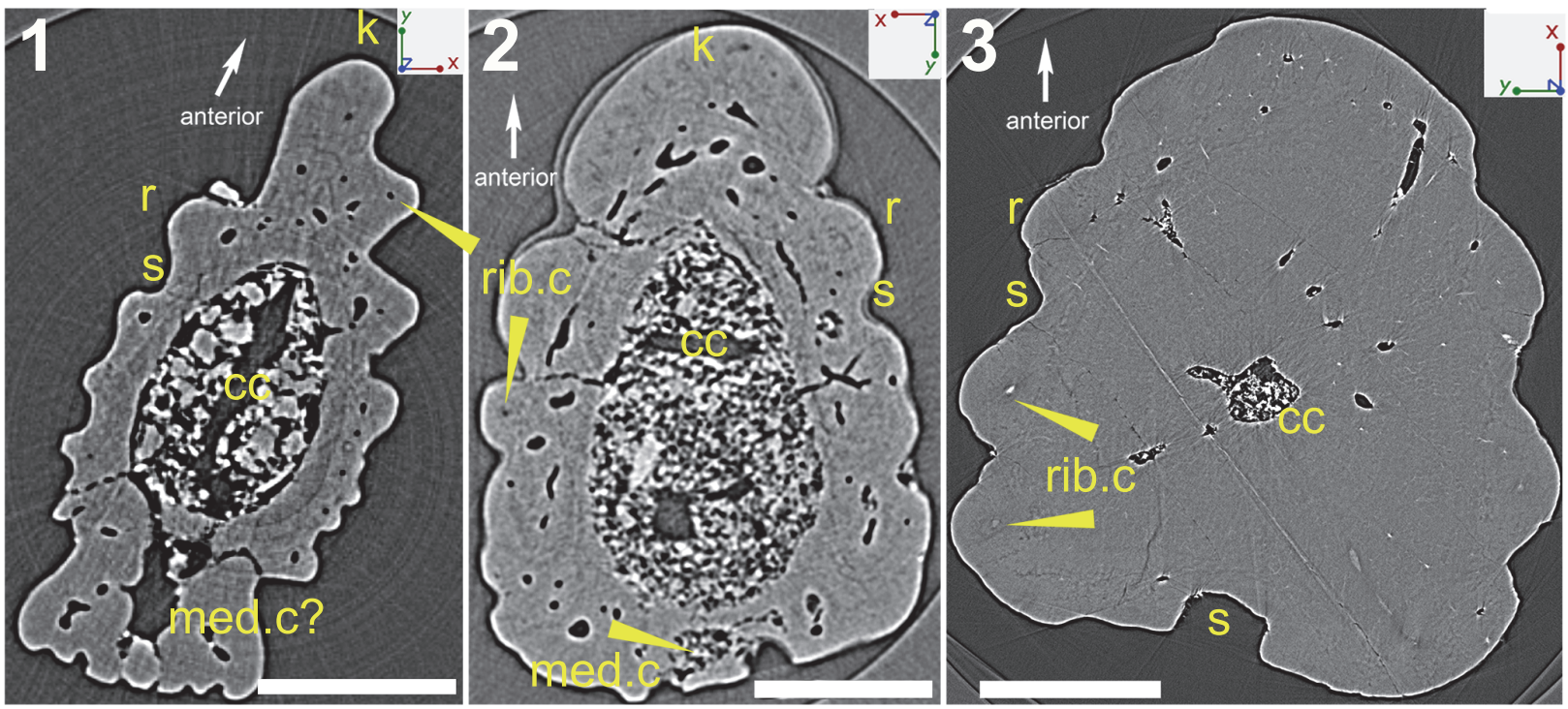

FIGURE 6. Virtual thin sections of (1), morphotype E; (2), morphotype F; and, (3), morphotype G. Scale bars equal $450 \mu \mathrm{m}$ (1 and 2) and $200 \mu \mathrm{m}$ (3). Abbreviations: cc, central cavity; k, keel; med.c, median canal; r, ribbing; rib.c, ribbing canals; s, sulcus.

there is a line that runs down the midline of it. Ornamentation on this morphotype is ribbed and has a prominent rounded anterior keel (Figure 2.6). The ribs on the lateral sides are wider than the sulci between them and they decrease in size posteriorly. The middle section of ribbing along the lateral surfaces is sandwiched between a wide, rounded anterior keel and an unornamented posterior surface that increases in size apically (Figure 2.6; in blue). This differs from morphotype $\mathrm{E}$ (Figure 2.5 ) in that the ribbing is rounder and there is no longitudinal median sulcus on the posterior surface of the spine.

A low-resolution virtual thin section (Figure 6.2) taken base-ward along the spine shows that there are at least two, maybe three, layers of vascular canals within the spine. The central cavity (Figure 6.2) is ovoid and uniform in shape. The tissue around the central cavity has very few vascular canals, which might mean that it is composed of a more compact tissue. A ring of vascular canals penetrates the main body of the spine, and a few ribbing canals (Figure 6.2) are also present within the ribbing. A median canal is also present posterior to the central canal. It is partially filled with sediment and appears to connect with two sulci that are located on the posterior surface of the spine. This dataset needs to be segmented before these details can be confirmed.

Morphotype G (Figure 2.7) is represented by a fragment of a straight and bilaterally symmetrical spine that includes the apex (Figure 2.7). The pos- terior surface is flat for much of the spine with a line running down the midline of it. Near the apex of the spine, this surface becomes slightly concave. The spine is ornamented with continuous ribs that are composed of closely spaced nodes (Figure $2.7 ; n$ ) with one of the ribs comprising the leading edge. A high-resolution virtual thin section (Figure 6.3) taken from tipward along the spine, shows a small, round central cavity (Figure 6.3) in the middle with a few larger radiating canals going out toward ribbing canals (Figure 6.3). Some of the ribbing canals are open and some appear white and have been secondarily in-filled.

\section{DISCUSSION}

\section{Morphological and Taxonomical Affinities}

Assigning the isolated fin spines described above to specific taxa is problematic, since no articulated acanthodians are known from the Silurian of the Baltic Basin. In fact, only one near complete acanthodian has been reported from strata older than the Devonian worldwide (Burrow and Rudkin, 2014). An assignment is further complicated by the lack of a real consensus regarding the details of the scale-based taxonomy of Baltic acanthodians, which was reviewed and revised in a series of sometimes contrasting works by Vergoossen (1997, 1999a, 1999b, 1999c, 2000, 2002a, 2002b, 2002c, 2003a, 2003b, 2004) and Valiukevičius (1998, 2003a, 2003b, 2004a, 2004b). Furthermore, the recently improved understanding of the 
squamation in early gnathostomes (e.g., Trinajstic, 2001; Brazeau, 2012; Burrow, 2013; Burrow et al., 2013, 2015, 2016; Chevrinais et al., 2017) will undoubtedly influence future designations of isolated material. On the other hand, the taxonomical framework based on isolated material that Vergoossen (2004) described from Ramsåsa site $E$ may enable an assignment of the spines treated herein on a higher taxonomic level. Referring the isolated spines to an order or family may also help us infer possible positions of the spines on the body by comparing them to articulated specimens of related taxa.

Three main acanthodian scale groups from the Baltic Basin is generally agreed upon, namely the "nostolepid", "gomphonchid", and poracanthodid scale types, all of which have been reported from Ramsåsa site $E$ (Vergoossen, 2004). "Nostolepids" have classically been viewed as climatiid acanthodians (Denison, 1979) and scales of Nostolepis-type are also referred to this family (Valiukevičius and Burrow, 2005), while "gomphonchids" and poracanthodids have been assigned to the Ischnacantidae Woodward 1891 and Poracanthodidae Vergoossen 1997 respectively, within the order Ischnacanthiformes (Burrow, 2013). Historically, poracanthodid scales were viewed as specialized scales along the lateral lines of "gomphonchid" acanthodians, and subsequently all poracanthodid remains were often referred to Gomphonchus Pander, 1856 (see Burrow, 2013). This view changed with the finds of articulated acanthodians that were solely covered in scales of poracanthodid type (e.g., Valiukevičius, 1992).

Morphotypes A-C and $\mathrm{G}$ are here considered as climatiid spines based on both morphological and histological similarities (see below). The ornament of these spines is composed of more or less nodose ridges, which is typical for Nostolepis (Denison, 1979). Considering that Nostolepis striata is the only scale-based taxon of this family that has been reported with certainty from Ramsåsa site $\mathrm{E}$ by Vergoossen (2004), the spines are putatively assigned to this taxon. Morphotype $A$ is similar to a spine fragment figured in Vergoossen (2004, figure 74 ) and Gross (1971, plate 8, figure 17), which Vergoossen (2004) assigned as a median, possibly anal, fin spine. A "nostolepid" affinity of this spine is also supported by histological descriptions of $N$. striata in Gross (1971, figure 14B) and Denison (1979), which show to be fully bony in cross-section with dentine ribbing. Valiukevičius (2003c) described the histology of Devonian Nostolepis spines, both intermediate and pectoral, as being formed by a bony core and ribs composed of dentine. Morphotype B shares histological features with $N$. striata as well, and its overall morphology resembles those described as prepectoral or intermediate/prepelvic spines for this taxon by Vergoossen (2004). Furthermore, it is similar to the prepelvic fin spines of another climatiid, Climatius reticulatus, figured in Burrow et al. (2015, figure $9 C)$. The overall asymmetry of morphotype $B$ also supports its placement as a paired spine. The recurved and laterally flattened morphotype C hosts two parallel rows of denticles along its posterior margin. This morphotype is here interpreted as a pectoral spine, because of its strong curvature and overall likeness to climatiid and diplacanthiid pectoral spines illustrated by Miles (1973, figure 33) and Burrow et al. (2016, figures 5.4, 14) respectively. However, it also shares similarities with the dorsal fin spines of some climatiid acanthodians (compare Burrow, 2007, figure 5; Burrow et al., 2013, figure 7B). Unlike the other climatiid fin spines from Ramsåsa, morphotype $C$ is composed entirely of dentine. Morphotype $G$ is less distinctive, but the ribs bear the typical noded ornament and its histology is "nostolepid"-like as well (Denison, 1979). Its symmetrical, elongated morphology suggests a median position, perhaps associated with a dorsal fin. Indeed, Vergoossen (2004) suggested a dorsal, median position of similar spines that were figured by Gross (1971, plate 8, figure $19,22 b, 24)$. The posterior dorsal fin spines in climatiids are generally smaller, straight, and often lack denticles (e.g., Burrow et al., 2013, figure 7), which could suggest such an affinity for morphotype G.

Vergoossen (2004) only reported two "gomphonchid" scales and no poracanthodids from the residues associated with the macro-remains at the NRM, but other samples from Ramsåsa site $E$ contained poracanthodid scales. Regarding this, and the uncertainties surrounding the morphological and histological distinctiveness of these remains when found disarticulated, morphotypes D-F are here regarded as ischnacanthiform spines. It is worth noting that they do resemble the poracanthodid spines described by Burrow (2013: e.g., figure 2I). These three morphotypes also resemble the spine fragments referred to as ischnacanthid spines by Vergoossen (2004, figures 81-83), and the "tiled" ornament described for ischnacanthid spines by Gross (1971) is visible in morphotype $E$. Furthermore, the histology of morphotype E (Figure 6.1) appears to be nearly identical to a Gomphonchus spine figured by Gross (1971, figure 
$24 \mathrm{~F}$ ), and the anterior part of morphotype $\mathrm{F}$ (Figure 6.2 ) is similar to another Gomphonchus spine in Gross (1971, figure 24G). The overall symmetry of morphotypes $D$ and $E$ indicates that they are median fin spines (possibly dorsal), but the asymmetry of morphotype $F$ suggests it as a paired spine.

Overall, the Ramsåsa fin spines have varied morphology and histology. Acanthodians are known to have several types of spines, including the symmetrical, short anal spines (morphotype A); asymmetrical short paired intermediate spines (morphotype B); and strongly curved pectoral spines hosting denticles on the posterior side (morphotype C). Paired pectoral fin spines were identified on Doliodus, a fossil probable stem-group chondrichthyan (Miller et al., 2003). A segmentation analysis revealed additional pairs of separate dermal spines in this taxon, which consequently combines shark-like characters with a set of acanthodian-like dermal spines (Maisey et al., 2017). All extant chondrichthyans have only median dorsal spines, with sharks having one per each of the two dorsal fins and holocephalans having one anterior to the first dorsal fin. Chondrichthyan spines from extant taxa are typically symmetrical, laterally compressed to different degrees, and are generally recurved posteriorly (Patterson, 1965; Maisey, 1979).

In extinct chondrichthyans, the dorsal fin spines display a wide range of morphologies from the large spine-brush complex in symmoriiforms (Maisey, 2009), the tubiform spines of xenacanths (Soler-Gijón, 1999; Beck et al., 2016), to the typical selachian fin spines in ctenacanthoids and hybodontoids (Zangerl, 1981; Stamberg, 2001). The median dorsal spines from the Ramsåsa assemblage, which are represented by morphotypes D, E and G, are also symmetrical and recurved, but some are much more laterally compressed than what is seen in both extinct and extant chondrichthyan material. Superficially, these morphotypes are similar to dorsal spines described in most ischnacanthiforms and the second dorsal fin spines in some climatiids (Denison, 1979).

\section{Histological Compositions of Ramsåsa Fin Spines - Comparison with Fossil and Extant Gnathostomes}

Developmental data of the fin spines from extant Callorhinchus, Heterodontus, and Squalus show that the central cavities house a supporting cartilage that extends to the very tip in mature spines (Maisey, 1979; Tovar-Ávila et al., 2008;
Jerve et al., 2014). Oval to rounded central cavities are present in morphotypes D-G (Figures 5 and 6) and decrease in size apically (Figures 5 and 6.3), suggesting the presence of a supporting cartilage that extends to the tip. Callorhinchus fin spines are generally more ornamented than those from extant sharks, having some longitudinal striations near the anterior portion of the spine surface and retrose nodes along the posterolateral margins. Xenacanth sharks had spines ornamented with longitudinal striae on the anterior face and denticles on the posterior side of the tip (Soler-Gijón, 1999; Beck et al., 2016), while dorsal fin spines of ctenacanths and hybodontoids can be covered in enameloid tubercles or nodes and may bear posterolateral denticles (Cappetta, 1987). Acanthodian spines are generally much more ornamented with ribbing or nodes (Denison, 1979), which is observed on all of the Ramsåsa morphotypes. Extant sharks can have a thickened anterior rib along the leading edge of the spine (Maisey, 1978; Irvine et al., 2006) that is similar to those observed on morphotypes $E$ and $F$ (Figure 6.1 and 6.2), and exaggerated in morphotype D (Figure 5).

Acanthodian fin spines have been described to have a tripartite structure (Denison, 1979; Burrow and Turner, 2010), consisting of an inner lamellar bone/dentine layer called the basal layer, a middle layer of trabecular dentine, and outer dentine ornament. Based on the scan data, the different morphotypes of acanthodian fin spines from Ramsåsa also show differences in composition. Morphotype A has a fully bony core, confirmed by the presence of cell spaces distributed throughout the body of the spine (Figure 3), and is covered in dentine ornament, like Ptomacanthus (Brazeau, 2012) and Nostolepis (Denison, 1979). The lack of cell spaces and uninterrupted thin trabecular canals radiating from the central canal of morphotype $C$ suggests that it is fully dentinous (Figure 4), like Machaeracanthus (Burrow et al., 2010; Botella et al., 2012). The scan slices from morphotype D show an inner layer of lamellar bone with a possible trabecular dentine covering (Figure 5.1). Scan slices of morphotype $E$ show a thicker ring of mineralized tissue around the central cavity (Figure 6.1), and data from morphotypes $D$ and $F$ show that the hard tissue around the central cavity is not very vascularized in these morphotypes (Figures 5 and 6.2). This suggests that these spines could have a tripartite structure similar to several other acanthodian spines (Denison, 1979; Burrow and Turner, 2010), including Ischnacanthus (Denison, 1979), Diplacanthus (Burrow et al., 2016), and Par- 
exus (Burrow et al., 2013). Denison (1979) also described a fourth layer of tissue, composed of either a thick inner "osteon" or "denteon" (cb) located between the basal layer (b) and the central cavity in the closed portions of acanthodian fin spines (also figured by Gross, 1971), and can be observed from the scan data for morphotype D (Figure 5).

The main tissues comprising extant chondrichthyan fin spines are different types of dentine, with each type making up different parts of the spine. The innermost part of the spine, called the trunk, is made of inward and outward growing orthodentine (Maisey, 1979). Inward and outward growing trunk dentine similar to that from extant chondrichthyans is also described from the fossil dorsal spines of the xenacanth shark Orthacanthus (Soler-Gijón, 1999; Beck et al., 2016), hybodont sharks (Maisey, 1978), and Mesozoic holocephalans (Patterson, 1965, Jerve et al., 2014). However, many fossil taxa lack a dentine trunk and have a spine that is composed primarily of trabecular dentine, including some Helodus (Patterson, 1965), Sphenacanthus (Maisey, 1982), ctenacanth sharks (Maisey, 1982; Stamberg, 2001), and sinacanth spines (Coates et al., 1998; Maisey, 2009). Coates et al. (1998) also reported a layer of acellular bone surrounding the trabecular dentine in the spine of Stethacanthus.

According to Maisey (1979), the trunk dentine is covered by mantle dentine, which is an inward growing layer of dentine that originates in contact with an epithelial fold and is associated with a set of vascular canals. The Callorhinchus spine departs from this organization due to the presence of a small portion of trabecular dentine positioned in the anteriormost portion of the spine (Halstead and Bunker, 1952; Jerve et al., 2014). The mantle dentine is covered with a hypermineralized cap composed of enameloid (Maisey, 1979) and thus it is not present where there is no enameloid. The enameloid cap covers the entire anterior portion of the spine in Squalus and Heterodontus, it is restricted to the anterior and posterior margins in Etmopterus and Callorhinchus, and it is absent in Oxynotus (Maisey, 1979; Tovar-Ávila et al., 2008). Enameloid on fossil chondrichthyan fin spines is not very common, even though it is reported from teeth and scales (Zangerl, 1981). This tissue is not present on any acanthodian fin spines, but acanthodian scales are sometimes covered by a hypermineralized cap (Denison, 1979; Chevrinais et al.,
2017). However, it is not possible to make any further inferences on this matter with the data at hand.

When mantle dentine is present in chondrichthyan fin spines, there is a set of canals associated with it called mantle canals (Maisey, 1979). In Squalus, the mantle dentine covers the lateral surfaces of the spine, while in Callorhinchus it is restricted to the leading edge (or anterior keel) and the ornamentation on the posterolateral margins. Topologically similar canals were figured by Gross (1971) in acanthodian fin spines and can be observed in almost all morphotypes of the Ramsåsa assemblage (referred to as ornament canals in Figures 3, 4, and 6). Both mantle canals from chondrichthyans and the ornament canals described from the Ramsåsa material are similar in that they are only associated with inward growing dentine. There is usually one ornament canal associated with each individual rib and these are connected by a smaller set of canals (Figure 2). Ornament canals in morphotype $\mathrm{C}$ can be elongated to create the ribbing or they can be clusters of canals to create the posteriorly facing nodes. These canals form a small network of looped canals within each unit of ornament. Dentine tubules can be observed projecting from the ornament canals of the nodes, which is similar to the ascending canals in the ornamentation covering the fin spine of the probable stem-osteichthyan Lophosteus, described by Jerve et al. (2016). However, denticles on the posterior side of the dorsal fin spine of the xenacanth shark Orthacanthus were also identified as individually grown, fully dentinous elements (Soler-Gijón, 1999). Furthermore, both chondrichthyan and acanthodian spines are usually covered in more or less continuous ornament along the entire length of the spine (Miles, 1973), even though it sometimes transforms into nodules toward the base (Burrow et al., 2015; morphotype B). While some acanthodians (e.g., Miles, 1973) bear stellate nodules resembling the odontodes of Lophosteus (Jerve et al., 2016) and acanthothoracid placoderms (Warren et al., 2000), these are never composed of more than one layer of tissue as opposed to the two generations of odontodes in Lophosteus (Jerve et al., 2016). Morphotype $\mathrm{D}$ presents a vascular network that differs from what is seen in morphotype $C$, as it appears to consist of many tapering radial canals that decrease in size distally from the central cavity. 


\section{Growth Patterns of Ramsåsa Fin Spines - Comparison with Fossil and Extant Gnathostomes}

The 3D data of the fin spines of the Ramsåsa material provide insights relating to their development when compared to the fin spine growth models from extant chondrichthyans. Burrow et al. (2015) suggested that some Climatius reticulatus pectoral spines grew as a result of the folding of a bony plate that fused along the posterior midline due to the presence of a median groove along the length of the posterior side of the spine. The data from the Ramsåsa material suggest that most of the spines grew in the same way as seen in most of the chondrichthyan fin spines, indicated by the longitudinal organization of the vascularization within them. In morphotypes $A$ and $C$ (Figures 3 and 4 , respectively) the largest vascular canals are longitudinal and connected by a series of thinner canals. All spines, except for morphotypes $A$ and $G$, have longitudinally directed median canals in the posterior part of the closed portion of the spine. The median canals extend for almost the entire length of the closed portion of the spine (Figures 4 and 5), but there is no data at the tip to suggest they extend the spine's full length. Many other acanthodian dorsal fin spines also show evidence for longitudinal growth by the presence of accessory canals that run the entire length of the fin spines (Burrow et al., 2016). Callorhinchus also has a median canal that runs the length of the closed portion of the spine (Jerve et al. 2014), which has also been identified in fossil sharks, such as Sphenacanthus (Maisey, 1982).

The exception to this is the short morphotype B (most likely an intermediate spine), which has a shallow, wide-open base and small ridges that radiate from a smooth and long main ridge (Figure 2.2). The morphology of this spine suggests that the ridge formed a growth center, but scan data is needed to confirm this. A similar morphology was identified in prepectoral spines of Doliodus, leading the authors to suspect that the ridge formed an apical growth center (Maisey et al., 2017). This is similar to the growth in spines of the placoderm Romundina, where the vascularization shows that the growth center is positioned along the upper portion of the anterior midline with new tissue being deposited posteriorly and proximally (Jerve, 2016; Jerve et al., 2016).

The fin spines of chondrichthyans have linear growth away from the body with the tip of the spine being the oldest part (Maisey, 1979; Burrow and Turner, 2010; Jerve et al., 2014). There are addi- tional areas of growth in dorsal fin spines from all extant spine-bearing chondrichthyans and some fossil chondrichthyans (e.g., Orthacanthus), which is marked by the presence of trunk dentine exhibiting both outward and inward growth (Maisey, 1979; Soler-Gijon, 1999; Tovar-Ávila et al., 2008; Beck et al., 2016). Callorhinchus and other holocephalan fin spines also have a trabecular component (Halstead and Bunker, 1952; Jerve et al., 2014). In the closed portion of these fin spines, the trunk forms from a mesenchymal primordium and dentine is deposited inward and outward from it (Jerve et al., 2014). In Squalus and Heterodontus, the layers of the trunk are relatively even in thickness, with the outward growing dentine delimited by the position of the mantle and the cartilage rod (Maisey, 1979; Jerve et al., 2014). In Callorhinchus, there is inward and outward growth, but the outer growing layer is thinner than the inner growing layer and some of these boundaries are marked by a transitional layer to trabecular dentine (Jerve et al., 2014).

Acanthodian fin spines with an inner denteon/ osteon layer seem to be topologically similar to the dorsal fin spines from extant chondrichthyans (see Denison, 1979; Burrow et al., 2016). Of course, this layer would represent only one direction of growth (inward toward the central cavity), but the thinner basal layer described by Denison (1979), and observable in morphotype D (Figure 5 ; b), could potentially represent a thinner outer growing layer. Machaeracanthus, whose fin spine is composed solely of trabecular dentine, shows evidence for inward and outward growth, and most likely grew similarly to chondrichthyan fin spines (Botella et al., 2012). It could be that the Machaeracanthus spine represents a trabecular dentine spine organization similar to that reported in Sphenacanthus by Maisey (1982), but this spine and other fossil spines could have layers that are difficult to identify without detailed knowledge of the mesenchymal organization during development, as seen with the trunk dentine in Callorhinchus (Jerve et al., 2014). Although it is not possible to fully explain the development of such a spine, its unique composition is rather unsurprising considering the vast differences in fin spine composition and growth exhibited by other acanthodians and in the Ramsåsa material. Nevertheless, the Ramsåsa spines show a larger similarity overall to chondrichthyan fin spines in composition and growth as they mostly seem to represent single, continuously growing entities (Jerve et al., 2016). This is in contrast to the spines of both Romundina and Lophosteus that 
are covered by several generations of individual odontodes (Jerve, 2016; Jerve et al., 2016).

Patterson (1965) suggested a general trend toward a reduction of trabecular dentine in holocephalans. This trend is also shown in fossil elasmobranchs and suggests that the presence of trabecular dentine in fin spines is primitive for (what was then considered) the chondrichthyan total group (Jerve et al., 2014). This means that there is no ideal overarching definition for a total group chondrichthyan fin spine, only compositional variations on a similar form. The compositional variability and growth patterns exhibited by the Ramsåsa fin spine material are in line with the increasing amount of evidence that place acanthodians within the chondrichthyan total group (Zhu et al., 2013; Giles et al., 2015; Burrow et al., 2016; Qiao et al., 2016). The only major tissue not abundantly present in most fossil elasmobranch (with the possible exception of Stethacanthus) and holocephalan spines that is present in acanthodian fin spines is bone (Ptomacanthus, Nostolepis). But if all acanthodians are true stem-chondrichthyans it is possible that the presence of bone then represents a primitive condition for total group chondrichthyan fin spines.

\section{CONCLUSIONS}

The acanthodian fin spine assemblage described here fits well within the taxonomic framework for the Ramsåsa site $E$ locality that Vergoossen (2004) developed based on scales and other fragmentary remains. The spines can only be confidently assigned in broader taxonomic terms as climatiid and ischnacanthiform spines, but they still provide valuable insights into acanthodian fin spine histological composition, as well as growth patterns when compared to histological studies of placoderms, fossil and extant chondrichthyans, and the stem-osteichthyan Lophosteus.

The scan data of the acanthodian fin spine morphotypes studied here demonstrate a great diversity of compositions, having a bony core covered in dentine ornament (morphotype A), a fully dentinous core (morphotype $\mathrm{C}$ ), or having a tripartite structure (morphotypes D-F). The tripartite structure of morphotypes D-F resembles the histology described for many other acanthodian spines (Denison, 1979; Burrow and Turner, 2010). Morphotype $D$ also displays another layer of tissue, which is similar to the inner growing bone ("osteon") that can be present in older parts of some acanthodian fin spines described by Denison (1979). The trabecular dentine in morphotype $D$ is similar to that in chondrichthyans such as Callorhinchus (Jerve et al., 2014), and some acanthodian spines (Botella et al., 2012).

A set of vascular canals are present in almost all morphotypes of the Ramsåsa assemblage (referred to as ornament canals) and could be interpreted as associated with a mantle dentinous layer as seen in chondrichthyans and acanthodians (Gross, 1971). However, the hypermineralized enameloid cap that covers the mantle dentine in extant chondrichthyans is entirely absent in the studied Ramsåsa fin spines, as in previously studied acanthodians.

The scan data of the Ramsåsa fin spines revealed a longitudinal organization of their vascularization, which suggests that the spines grew in a similar fashion as most of the chondrichthyan fin spines. The inner structure of the compact bone observed in morphotype $D$ also suggests that this tissue could be growing in a similar way as the trunk dentine in Callorhinchus. Furthermore, comparisons of the Ramsåsa spines to the growth of Callorhinchus, Heterodontus, and Squalus suggest the presence of a supporting cartilage extending to the tip in several of the Ramsåsa spines. Morphotype B seems to depart from this pattern as its overall morphology indicates similarities to the growth pattern of spines present in both the stemchondrichthyan Doliodus and the placoderm Romundina, but scan data of this spine is needed to confirm this.

The histological composition and growth pattern of the Ramsåsa fin spines - identified from their morphologies as acanthodian fin spines much more resemble those of chondrichthyans than those of placoderms and osteichthyans. This work is therefore consistent with the placement of acanthodians on the chondrichthyan stem. However, since three-dimensional histological studies using synchrotron-microtomography data is still an emerging field of investigation, there is a general lack of directly comparable data. Therefore, these results should be regarded as preliminary and must be compared to detailed histological descriptions of fin spines from articulated material and other gnathostome groups, as well as tested in a phylogenetic context.

\section{ACKNOWLEDGMENTS}

We would like to thank T. Mörs and the Naturhistoriska Riksmuseet in Stockholm for facilitating the loan of the material, $\mathrm{H}$. Blom for supporting the early stages of this project, and Q. Qu for assistance during the scan session at the ESRF. 
Lastly, we would like to thank P. Tafforeau for his time and efforts while collecting and reconstructing the data that were acquired at the ESRF (proposal EC688). This project was funded by VR project 2006-5558 that was awarded to $\mathrm{H}$. Blom at
Uppsala University. S. Sanchez was supported by an ERC Advanced Investigator Grant 233111 awarded to P.E. Ahlberg. Many thanks to the anonymous reviewers for their helpful comments and suggestions.

\section{REFERENCES}

Beck, K.G., Soler-Gijón, R., Carlucci, J.R., and Willis, R.E. 2016. Morphology and histology of dorsal spines of the xenacanthid shark Orthacanthus platypternus from the Lower Permian of Texas, USA: palaeobiological and palaeoenvironmental implications. Acta Palaeontologica Polonica, 61:97-117. http://dx.doi.org/10.4202/app.00126.2014

Berg, L.S. 1940. Classification of fishes, both recent and fossil. Trudy Instituta Zoologicheskikh Akademiia Nauk, 5:85-517.

Botella, H., Martinez-Perez, C., and Soler-Gijón, R. 2012. Machaeracanthus goujeti n. sp. (Acanthodii) from the Lower Devonian of Spain and northwest France, with special reference to spine histology. Geodiversitas, 34:761-783. https://doi.org/10.5252/g2012n4a3

Brazeau, M.D. 2009. The braincase and jaws of a Devonian 'acanthodian' and modern gnathostome origins. Nature, 457:305-308. https://doi:10.1038/nature07436

Brazeau, M.D. 2012. A revision of the anatomy of the Early Devonian jawed vertebrate Ptomachanthus anglicus Miles. Palaeontology, 55:355-367. https://doi:10.1111/j.14754983.2012.01130.x

Burrow, C.J. 2007. Early Devonian (Emsian) acanthodian faunas of the western USA. Journal of Paleontology, 81:824-840. https://doi.org/10.1666/pleo06-009.1

Burrow, C.J. 2013. Reassessment of Ischnacanthus? scheii Spjeldnaes (Acanthodii, Ischnacanthiformes) from the latest Silurian or earliest Devonian of Ellesmere Island, arctic Canada 1. Canadian Journal of Earth Sciences, 50:945-954. https://doi.org/10.1139/cjes2013-0068

Burrow, C.J., Davidson, R.G., den Blaauwen, J.L., and Newman, M.J. 2015. Revision of Climatius reticulatus Agassiz, 1844 (Acanthodii, Climatiidae), from the Lower Devonian of Scotland, based on new histological and morphological data. Journal of Vertebrate Paleontology, 35:e913421. https://doi.org/10.1080/02724634.2014.913421

Burrow, C.J., den Blaauwen, J.L., Newman, M., and Davidson, R. 2016. The diplacanthid fishes (Acanthodii, Diplacanthiformes, Diplacanthidae) from the Middle Devonian of Scotland. Palaeontologia Electronica 19.1.10A:83p, 72.8 MB. https://doi.org/10.26879/601 http://palaeo-electronica.org/content/2016/1398-scottish-diplacanthid-fishes.

Burrow, C.J., Desbiens, S., Ekrt, B., and Südkamp, W.H. 2010. A new look at Machaeracanthus, p. 59-84. In Elliott, D.K., Maisey, J.G., Yu, X., and Miao, D. (eds.), Morphology, Phylogeny and Paleobiogeography of Fossil Fishes. Verlag Dr. Friedrich Pfeil, Munich.

Burrow, C.J., Newman, M.J., Davidson, R.D., and den Blaauwen, J.L. 2013. Redescription of Parexus recurvus, an Early Devonian acanthodian from the Midland Valley of Scotland. Alcheringa: an Australasian Journal of Palaeontology, 37:392-414. http://dx.doi.org/10.1080/ 03115518.2013.765656

Burrow, C.J. and Rudkin, D. 2014. Oldest near-complete Acanthodian: The first vertebrate from the Silurian Bertie Formation konservat-lagerstätte, Ontario. PLOS ONE 9(8):e104171. https://doi:10.1371/journal.pone.0104171

Burrow, C.J. and Turner, S. 2010. Reassessment of "Protodus" scoticus from the Early Devonian of Scotland, p. 123-144. In Elliott, D.K., Maisey, J.G., Yu, X., and Miao, D. (eds.), Morphology, Phylogeny and Paleobiogeography of Fossil Fishes. Verlag Dr. Friedrich Pfeil, Munich.

Cappetta, H. 1987. Chondrichthyes II: Mesozoic and Cenozoic Elasmobranchii, p. 1-193. In Schultze, H-P (ed.), Handbook of Paleoichthyology, Vol. 3B. Stuttgart, Gustav Fischer Verlag.

Chen, D., Blom, H., Sanchez, S., Tafforeau, P., and Ahlberg, P.E. 2016. The stem osteichthyan Andreolepis and the origin of tooth replacement. Nature, 539:237-241. http://doi:10.1038/ nature19812

Chevrinais, M., Jean-Yves, S., and Cloutier, R. 2017. From body scale ontogeny to species ontogeny: histological and morphological assessment of the Late Devonian acanthodian 
Triazeugacanthus affinis from Miguasha, Canada. PLOS ONE, 12(4), e0174655. https:// doi.org/10.1371/journal.pone.0174655

Coates, M.I., Sequeira, S.E.K., Sansom, I.J., and Smith, M.M. 1998. Spines and tissues of ancient sharks. Nature, 396: 729-730. http://doi:10.1038/25467

Davis, S.P., Finarelli, J.A., and Coates, M.I. 2012. Acanthodes and shark-like conditions in the last common ancestor of modern gnathostomes. Nature, 486:247-250. http://doi:10.1038/ nature11080

Denison, R.H. 1979. Acanthodii. Handbook of Paleoichthyology, Pt. 5. Gustav Fischer Verlag, Stuttgart.

Dupret, V., Sanchez, S., Goujet, D., Tafforeau, P., and Ahlberg, P.E. 2010. Bone vascularization and growth in placoderms (Vertebrata): The example of the premedian plate of Romundina stellina Ørvig, 1975. Comptes-rendus Palevol, 9:369-375.

Giles, S., Rücklin, M., and Donoghue, P.C.J. 2013. Histology of "placoderm" dermal skeletons: Implications for the nature of the ancestral gnathostome. Journal of Morphology, 274:627644. http:doi: 10.1002/jmor.20119

Giles, S., Friedman, M., and Brazeau, M. 2015. Osteichthyan-like cranial conditions in an Early Devonian stem gnathostome. Nature, 520:82-85. http:doi:10.1038/nature14065

Gross, W. 1971. Downtonische und dittonische Acanthodier-Reste des Ostseegebietes. Palaeontographica A, 136:1-82.

Grönwall, K.A. 1897. Öfversikt af Skånes yngre öfversiluriska bildningar. Geologiska Föreningens i Stockholm Förhandlingar, 19:188-244. (in Swedish)

Halstead, B.W. and Bunker, N.C. 1952. The venom apparatus of the Ratfish, Hydrolagus colliei. Copeia, 3:128-138.

Irvine, S.B., Stevens, J.D., and Laurenson, L.J.B. 2006. Comparing external and internal dorsal-spine bands to interpret the age and growth of the giant lantern shark, Etmopterus baxteri (Squaliformes: Etmopteridae). Environmental Biology of Fishes, 77:253-264. https:// doi.org/10.1007/s10641-006-9130-4

Jeppsson, L. and Laufeld, S. 1986. The Late Silurian Öved-Ramsåsa Group in Skåne, Southern Sweden. Sveriges Geologiska Undersökning, Serie Ca 58:1-45.

Jerve, A. 2016. Development and three-dimensional histology of vertebrate dermal fin spines. Unpublished PhD Thesis, Uppsala University, Uppsala, Sweden.

Jerve, A., Johanson, Z., Ahlberg, P.E., and Boisvert, C. 2014. Embryonic development of fin spines in Callorhinchus milii (Holocephali); implications for chondrichtyan fin spine evolution. Evolution and Development, 16:339-353. http://doi:10.1111/ede.12104

Jerve, A., Qu, Q., Sanchez, S., Blom, H., and Ahlberg, P.E. 2016. Three-dimensional paleohistology of the scale and median fin spine of Lophosteus superbus (Pander 1856). PeerJ 4:e2521. https://doi.org/10.7717/peerj.2521

Labiche, J-C., Mathon, O., Pascarelli, S., Newton, M.A., Guilera Ferre, G., Curfs, C., Vaughan, G., Homs, A., and Fernandez Carreiras, D. 2007. The fast readout low noise camera as a versatile $\mathrm{X}$-ray detector for time resolved dispersive extended X-ray absorption fine structure and diffraction studies of dynamic problems in materials science, chemistry, and catalysis. Review of Scientific Instruments, 78:091301-091311. http://doi:10.1063/1.2783112

Larsson, K. 1979. Silurian tentaculitids from Gotland and Scania. Fossils \& Strata, 11:1-180.

Lehman, J-P. 1937. Les Poissons du Downtonien de la Scanie (Suède). Mémoire de la Faculté des Sciences de l' Université de Paris, No d'ordre, 664:1-98.

Maisey, J.G. 1978. Growth and form of finspines in hybodont sharks. Palaeontology 21:657-666.

Maisey, J.G. 1979. Fin spine morphogenesis in squalid and heterodontid sharks. Zoological Journal of the Linnean Society 66:161-183.

Maisey, J.G. 1982. Studies on the Paleozoic selachian genus Ctenacanthus Agassiz: No. 2: Bythiacanthus St. John and Worthen, Amelacanthus, new genus, Eunemacanthus St. John and Worthen, Sphenacanthus Agassiz, and Wodnika Münster. American Museum Novitates, 2722:1-24.

Maisey, J.G. 2009. The spine-brush complex in symmoriiform sharks (Chondrichthyes; Symmoriiformes), with comments on dorsal fin modularity. Journal of Vertebrate Paleontology 29:14-24. http://dx.doi.org/10.1671/039.029.0130

Maisey, J.G., Miller, R., Pradel, A., Denton, J.S., Bronson, A., and Janvier, P. 2017. Pectoral Morphology in Doliodus: Bridging the 'Acanthodian'-Chondrichthyan Divide. American Museum Novitates, 3875:1-15. 
Markert, F. 1896. Die Flossenstacheln von Acanthias. Ein Beitrag zur Kenntniss der Hartsubstanzgebilde der Elasmobranchier. Zoolische Jahrbücker Anatomie, 9:665-722. (In German)

Martin, T., Douissard, P-A., Couchaud, M., Rack, A., Cecilia, A., Baumbach, T., and Dupré, K. 2009. LSO-based single crystal film scintillator for synchrotron-based hard X-ray microimaging. IEEE Transactions on Nuclear Science, 56:1412-1418. https://doi:10.1109/ TNS.2009.2015878

Mehlqvist, K., Larsson, K., and Vajda, V. 2014. Linking upper Silurian terrestrial and marine successions Palynological study from Skåne, Sweden. Review of Palaeobotany and Palynology, 202:1-14. https://doi.org/10.1016/j.revpalbo.2013.12.001

Mehlqvist, K., Steemans, P., and Vajda, V. 2015. First evidence of Devonian strata in Sweden A palynological investigation of Övedskloster drillcores 1 and 2, Skåne, Sweden. Review of Palaeobotany and Palynology, 221:144-159. https://doi.org/10.1016/j.revpalbo.2015.06.007

Miles, R. 1973. Articulated acanthodian fishes from the Old Red Sandstone of England, with a review of the structure and evolution of the acanthodian shoulder-girdle. Bulletin of the British Museum (Natural History), 24:111-213.

Miller, R.F., Cloutier, R., and Turner, S. 2003. The oldest articulated chondrichthyan from the Early Devonian period. Nature, 425:501-504. http://doi:10.1038/nature02001

Pander, C.H. 1856. Monographie der fossilen Fische der silurischen Systems der RussischBaltischen Gouvernements. Kaiserlichen Akademie des Wissenschaften, St. Petersburg.

Patterson, C. 1965. The phylogeny of the chimaeroids. Philosophical Transactions of the Royal Society of London, Series B Biological Sciences, 757(249):101-219.

Qiao, T., King, B., Long, J.A., Ahlberg, P.E., and Zhu, M. 2016. Early gnathostome phylogeny revisited: multiple method consensus. PLOS ONE 11(9):e0163157. http://doi:10.1371/ journal.pone.0163157

Qu, Q., Blom, H., Sanchez, S., and Ahlberg, P.E. 2015. Three-dimensional virtual histology of Silurian osteostracan scales revealed by synchrotron radiation microtomography. Journal of Morphology, 276:873-888. http://doi:10.1002/jmor.20386

Qu, Q., Sanchez, S., Blom, H., Tafforeau, P., and Ahlberg, P.E. 2013. Scales and Tooth Whorls of Ancient Fishes Challenge Distinction between External and Oral 'Teeth'. PLOS ONE 8(8):e71890. http://doi:10.1371/journal.pone.0071890.

Sanchez, S., Ahlberg, P.E., Trinajstic, K.M., Morone, A., and Tafforeau, P. 2012. Threedimensional synchrotron virtual paleohistology: a new insight into the world of fossil bone microstructures. Microscopy and Microanalysis, 18:1095-1105. http://doi: 10.1017/ S1431927612001079

Sanchez S., Tafforeau P., and Ahlberg P.E. 2014. The humerus of Eusthenopteron: a puzzling organization presaging the establishment of tetrapod limb bone marrow. Proceedings of the Royal Society of London B, 281:20140299. http://dx.doi.org/10.1098/rsbp.2014.0299

Siveter, D.J. 1989. Ostracodes, p. 252-264. In Holland, C.H. and Bassett, M.G. (eds.), A Global Standard for the Silurian System. National Museum of Wales, Cardiff.

Soler-Gijón, R. 1999. Occipital Spine of Orthacanthus (Xenacanthidae, Elasmobranchii): Structure and Growth. Journal of Morphology, 242:1-45. http://doi:10.1002/(SICl)10974687(199910)242:1<1::AID-JMOR2>3.0.CO;2-9

Stamberg, S. 2001. Fin spine of a ctenacanthoid shark (Elasmobranchii, Ctenacanthoidea) from the Upper Stephanian of the Krkonoše Piedmont Basin (Bohemia). Bulletin of the Czech Geological Survey, 76:141-148.

Tovar-Ávila, J., Izzo, C., Walker, T.I., Braccini, J.M., and Day, R.W. 2008. Dorsal-fin spine growth of Heterodontus portusjacksoni: a general model that applies to dorsal-fin spines of chondrichthyans? Canadian Journal of Fisheries and Aquatic Sciences 65(1):74-82. https:// doi.org/10.1139/f07-146

Trinajstic, K. 2001. Acanthodian microremains from the Frasnian Gneudna Formation, Western Australia. Records of the Western Australia, 20:187-198.

Valiukevičius, J. 1992. First articulated Poracanthodes from the Lower Devonian of Severnaya Zemlya, p. 193-213. In Mark- Kurik, E. (ed.), Academia 1, Fossil Fishes as Living Animals. Academy of Sciences of Estonia, Tallinn.

Valiukevičius, J.1998. Acanthodians and zonal stratigraphy of Lower and Middle Devonian in East Baltic and Byelorussia. Palaeontographica Abteilung A, 248:1-53.

Valiukevičius, J. 2003a. New Silurian Nostolepids (Acanthodii, Pisces) of Lithuania. Geologija, 42:51-68. 
Valiukevičius, J. 2003b. New Late Silurian to Middle Devonian acanthodians of the TimanPechora region. Acta Geologica Polonica, 53:209-245.

Valiukevičius, J. 2003c. Devonian acanthodians from Severnaya Zemlya Archipelago (Russia). Geodiversitas, 25:131-204.

Valiukevičius, J. 2004a. Silurian acanthodian succession of the Lužni-4 borehole (Latvia). Acta Universitas Latviensis, 679:120-147.

Valiukevičius, J. 2004b. New Wenlock-Pridoli (Silurian) acanthodian fishes from Lithuania. Acta Palaeontologica Polonica, 49:147-160.

Valiukevičius, J. and Burrow, C.J. 2005. Diversity of tissues in acanthodians with "Nostolepis"type histological structure. Acta Palaeontologica Polonica, 50:635-649.

Vergoossen, J.M.J. 1997. Revision of poracanthodid acanthodians, p. 44-46. In Ivanov, A., Wilson, M.V.H. and Zhuravlev, A. (eds.), Palaeozoic Strata and Fossils of the Eurasian Arctic. Abstracts. Ichthyolith Issues, Special Publication 3.

Vergoossen, J.M.J. 1999a. Late Silurian fish microfossils from Helvetesgraven, Skåne (Southern Sweden) (I). Geologie en Mijnbouw, 78:267-280. https://doi.org/10.1023/A:1003866312419

Vergoossen, J.M.J. 1999b. Siluro-Devonian microfossils of Acanthodii and Chondrichthyes (Pisces) from the Welsh Borderland/south Wales. Modern Geology, 24:23-90.

Vergoossen, J.M.J. 1999c. Late Silurian fish microfossils in an East Baltic-derived erratic from Oosterhaule, with a description of new acanthodian taxa. Geologie en Mijnbouw, 78:231-251. https://doi.org/10.1023/A:1003803814177

Vergoossen, J.M.J. 2000. Acanthodian and chondrichthyan microremains in the Siluro-Devonian of the Welsh Bordeland, Great Britain, and their biostratigraphical potential. Welsh borderlands, p. 175-199. In Blieck, A. and Turner, S. (eds.), Palaeozoic Vertebrate Biochronology and Global Marine/Non-Marine Correlation, Final Report of IGCP 328. Courier Forschungsinstitut Senckenberg 223.

Vergoossen, J.M.J. 2002a. Late Silurian fish microfossils from Ramsåsa, locality H, Scania, south Sweden, with some remarks on the body zonation scheme used in thelodont studies. Scripta Geologica, 123:41-69.

Vergoossen, J.M.J. 2002b. Late Silurian fish microfossils from Klinta and Rinnebäcks Bro (Scania, south Sweden), with remarks on the morphology of Nostolepis striata trunk scales. Scripta Geologica, 123:71-92.

Vergoossen, J.M.J. 2002c. Late Silurian fish microfossils from Ramsåsa (sites D and 'south of church'), Skåne, south Sweden. Scripta Geologica, 123:93-158.

Vergoossen, J.M.J. 2003a. First record of fish microfossils from Ramsåsa, site C, Skåne, southern Sweden. Scripta Geologica, 126:1-78.

Vergoossen, J.M.J. 2003b. Fish microfossils from the upper Silurian Öved Sandstone Formation, Skåne, Southern Sweden - A paleontological appraisal of biostratigraphical tools. Unpublished PhD Thesis, University of Groningen, Groningen, Netherlands.

Vergoossen, J.M.J. 2004. Fish microfossils from Ramsåsa, site E, Scania, southern Sweden (mid Palaeozoic). Scripta Geologica, 127:1-70.

Warren, A., Currie, B.P, Burrow, C.J., and Turner, S. 2000. A redescription and reinterpretation of Gyracanthides murrayi Woodward 1906 (Acanthodii, Gyracanthidae) from the Lower Carboniferous of the Mansfield Basin, Victoria, Australia. Journal of Vertebrate Paleontology, 20:225-242. https://doi:10.1671/0272-4634(2000)020[0225:ARAROG]2.0.CO;2

Wigforss-Lange, J. 1999. Carbon isotope ${ }^{13} \mathrm{C}$ enrichment in Upper Silurian (Whitcliffian) marine calcareous rocks in Scania, Sweden. Geologiska Föreningens i Stockholm Förhandlingar, 121:273-279. http://dx.doi.org/10.1080/11035899901214273

Wigforss-Lange, J. 2007. Tidal facies in the Upper Silurian Öved Ramsåsa Group of Scania, Sweden: linkages of radial and cerebroid ooids and evaporite tracers to subtidal lagoonal environment. Geologiska Föreningens i Stockholm Förhandlingar, 129:8-15.

Woodward, A.S. 1891. Catalogue of the Fossil Fishes in the British Museum (Natural History), 2. British Museum (Natural History), London.

Zangerl, R. 1981. Chondrichthyes I: Paleozoic Elasmobranchii, 1-110. In Schultze, H-P (ed.), Handbook of Paleoichthyology, Vol. 3A. Gustav Fischer Verlag, Stuttgart.

Zhu, M., Yu, X., Ahlberg, P.E., Choo, B., Lu, J., Qiao, T., Qu, Q., Zhao, W., Jia, L., Blom, H., and Zhu, Y.A. 2013. A Silurian placoderm with osteichthyan-like marginal jaw bones. Nature, 502:188-193. http://doi:10.1038/nature12617

Zhu, M., Yu, X., and Janvier, P. 1999. A primitive fossil fish sheds light on the origin of bony fishes. Nature, 397:607-610. http://doi:10.1038/nature17594 
Zhu, M., Zhao, W., Jia, L., Lu, J., Qiao, T., and Qu, Q. 2009. The oldest articulated osteichthyan reveals mosaic gnathostome characters. Nature, 458: 469-474. http://doi:10.1038/

nature07855 